DOI https://doi.org/10.30525/978-9934-26-039-1-100

\title{
ЗМІНА ПАРАДИГМИ У ВИКЛАДАННІ ГРАМАТИКИ
}

\author{
Самаріна B. B. \\ кандидат філологічних наук, доцент, \\ дочент кафедри німецької філології і перекладу \\ Харківського начіонального університету імені В. Н. Каразіна \\ м. Харків, Україна \\ Шахматова О. В. \\ старший викладач кафедри міжкультурної комунікачії \\ та іноземної мови \\ Національного технічного університету \\ «Харківський політехнічний інститут» \\ м. Харків, Україна
}

3 підйомом когнітивної лінгвістики відбувається зміна парадигми в концепції мови та граматики, що має важливі наслідки для вивчення мови та досліджень $[3 ; 7 ; 8 ; 9 ; 18 ; 19]$.

Перший важливий аспект цієї зміни парадигми стосується переважно орієнтованої на синтаксис та формальної концепції граматики, яка програє на користь розуміння граматики, орієнтованої на значення $[11$, c. 8$]$. Граматика більше не розуміється як абстрактний та довільний набір правил, але разом із лексиконом вона утворює континуум символічних структур, що складається 3 форми та значення [12, с. 67]. Відповідно, наприклад, символічна структура пасивної конструкції має таке саме значення, як символічна структура слова «таблиця». Однак найбільш вражаючою різницею між словом «таблиця» та пасивною конструкцією $є$ ступінь абстрактності [10, с. 22] відповідних символічних структур: тоді як значення компонента слова «таблиця» $\epsilon$ відносно конкретним і безпосереднім, значення пасивної конструкції $є$ більш абстрактним і багатошаровим [15, с. 51]. Це призводить до першого важливого для викладання граматики розуміння, а саме до того, що для успішного засвоєння граматичних конструкцій також обов'язково засвоєння їхнього змісту [12]. Талмі $[18$, с. 21] пропонує більш детальну характеристику семантичної функції граматики шляхом розмежування понятійного змісту (лексики) та концептуальної структури (граматики) когнітивних уявлень. Талмі припускає, що при кожному мовному висловлюванні концептуальний зміст певним чином структурується в 
рамках граматики. Спосіб структурування концептуального змісту відображає загальні організаційні принципи концептуальної системи i, отже, людського пізнання, яке Еванс і Грін [5, с. 193] називають когнітивною прихильністю когнітивної лінгвістики. Це виявляє другий важливий аспект зміни парадигми в когнітивно-лінгвістичній концепції граматики - на відміну від генеративної граматики, мова розглядається як невід'ємна частина людського пізнання, символічна система якої пов'язана 3 аспектами сприйняття та уяви і тому $\epsilon$ концептуально мотивованою [5; 17]. Таким чином, розуміють лінгвістичні та ментальні категорії на основі конкретних фізичних переживань (наприклад, рух, тиск, сила, співвідношення «частина - ціле», вертикальність тощо) [5]. Передача цього конкретного досвіду більш абстрактним поняттям відбувається за допомогою процесів метафоризації (так званого мапування) [6], центрального компоненту концептуальної теорії метафори людської думки і дії. Крім того, інші автори показали цю концептуальну мотивацію та образність граматики на основі принципів загального пізнання та сприйняття фізичних переживань [10; 18$]$. Хоча ці підходи не були розроблені з метою навчання мові, вони пропонують цінні імпульси для формулювання альтернативного, орієнтованого на значення пояснювального підходу до граматики, який сумісний з результатами когнітивних досліджень і таким чином може досягти вищої психологічної правдоподібності [5, с. $17 ; 16 ; 20]$.

Третім важливим аспектом зміни парадигми є характер засвоєння мови на основі використання [13, с. 628; 2, с. 429]. Відповідно до цього, розпізнають низку спільних рис у різних мовних висловлюваннях (події використання) і виводять своєрідний зразок або схему $[12,13]$ 3 вищим ступенем абстракції. Зростаюча схематизація та категоризація граматичних структур, їх також називають закріпленням [9; 4] може мати місце лише шляхом розгляду конкретних мовних виразів із самого введення. Це призводить до важливого для викладання граматики наслідку, а саме явне пояснення правил жодним чином не може замінити зростаючу схематизацію та категоризацію мовних висловлювань граматичної структури, оскільки перше пояснює лише закономірності окремих висловлювань [1, с. 440].

Слід зазначити, що конкретні фізичні переживання мотивують як семантичні, так і синтаксичні аспекти мови, і що для цього необхідні певні процеси метафоризації [14]. I навпаки, це також означає, що ефективне викладання граматики має зосереджуватися на концептуальній мотивації граматики та ініціювати відповідні процеси метафоризації - за допомогою так званих граматичних метафор. Перш 
ніж обговорювати викладання граматики на основі граматичних метафор, слід детальніше пояснити зв'язок між метафоризацією, образністю та граматикою.

\section{Література:}

1. Achard, Michel (2008), Teaching construal: Cognitive pedagogical grammar. In: Robinson \& Ellis (Hrsg.), P. 432-455.

2. Behrens, Heike (2009), Konstruktionen im Spracherwerb. Zeitschrift für Germanistische Linguistik 37: № 3. P. 427-444.

3. Croft, William (2001), Radical Construction Grammar: Syntactic Theory in Typological Perspective. Oxford: Oxford University Press.

4. Ellis, Nick C. (2008), Usage-based and form-focused language acquisition: The associative learning of constructions, learned attention, and the limited L2 endstate. In: Robinson \& Ellis (Hrsg.), P. 372-405.

5. Evans, Vyvyan \& Green, Melanie (2006), Cognitive Linguistics. An Introduction. Mahwah, N.J: L. Erlbaum.

6. Gibbs, Raymond W. \& Ferreira, Luciane C. (2011), Do people infer the entailments of conceptual metaphors during verbal metaphor understanding? In: Brdar et al. (Hrsg.), P. 221-236.

7. Kay, Paul \& Fillmore, Charles (1999), Grammatical constructions and linguistic generalizations: the What's X doing Y construction. Language 75, P. 1-34.

8. Lakoff, George \& Johnson, Mark (1980), Metaphors we Live by. Chicago: The University of Chicago Press.

9. Langacker, Ronald W. (1991), Descriptive Application. Foundations of Cognitive Grammar, Bd. 2. Stanford: Stanford University Press.

10. Langacker, Ronald W. (2008a), Cognitive Grammar. A Basic Introduction. Oxford/New York: Oxford University Press.

11. Langacker, Ronald W. (2008b), The relevance of cognitive grammar for language pedagogy. In: de Knop \& de Rycker (Hrsg.), P. 7-35.

12. Langacker, Ronald W. (2008c), Cognitive grammar as a basis for language construction. In: Robinson \& Ellis (Hrsg.), P. 66-88.

13. Langacker, Ronald W. (2009), A dynamic view of usage and language acquisition. Cognitive Linguistics 20: № 3. P. 627-640.

14. Littlemore, Jeanette \& Low, Graham (2006a), Metaphoric competence and communicative language ability. Applied Linguistics 27: № 2. P. 268-294.

15. Meex, Birgitta \& Mortelmans, Tanja (2002), Grammatik und Kognition. Deutsch anders gedacht. Germanistische Mitteilungen 56, 48-66. 
16. Nuyts, Jan (2011), Pattern versus process concepts of grammar and mind. In: Brdar et al. (Hrsg.), P. 47-66.

17. Scheller, Julia (2008), Grammatik, Kognition und Imagination. Zeitschrift für Interkulturellen Fremdsprachenunterricht 13: 2 [Online unter http://zif.spz.tu-darmstadt.de/jg-13-2/beitrag/Scheller1.htm. 27.03.2013].

18. Talmy, Leonard (2000), Toward a cognitive semantics. Band 1: Concept Structuring Systems. Cambridge: MIT Press.

19. Tomasello, Michael (2003), Constructing a Language: A Usagebased Theory of Language Acquisition. Cambridge: Harvard University Press.

20. Wildgen, Wolfgang (2008), Kognitive Grammatik: Klassische Paradigmen und neue Perspektiven. Berlin: de Gruyter.

DOI https://doi.org/10.30525/978-9934-26-039-1-101

\title{
НЕОБХІДНІСТЬ РОЗШИРЕННЯ ВИБОРУ ІНТЕГРАТИВНИХ ЕЛЕКТИВНИХ КУРСІВ У СТАРШІЙ ШКОЛІ
}

\author{
Сорочан Л. Ф. \\ викладач кафедри англійської мови з методикою викладання \\ Криворізького державного педагогічного університету \\ м. Кривий Ріг, Дніпропетровська область, Україна
}

В умовах реформування та профілізації сучасної старшої школи в Україні активно впроваджується інтегроване навчання іноземних мов, забезпечуючи якісну підготовку учнів засобами міжпредметних зв'язків. На думку Сажко Л. А., саме інтегративна основа навчання іноземних мов як процес взаємопов'язаного формування мовленнєвої, мовної, лінгвосоціокультурної та навчально-стратегічної компетентностей на основі зразків іншомовної культури із залученням навчальних матеріалів інших предметів, використанням різноманітних засобів і форм навчання розширює пізнавальні інтереси учнів, розвиває їхні здібності, стимулює до самостійної та творчої діяльності [3, с. 2]. На нашу думку, у профільній старшій школі впровадження міжпредметних зв'язків має бути не тільки у використанні матеріалів уроків інших навчальних дисциплін, a, насамперед, через різноманітні інтегративні елективні курси (курси на вибір). В роботах дослідників вказано, що поєднання інтегративного курсу, який складається зі змістових фрагментів різних предметів, а також додаткового змісту, який раніше не входив до навчального процесу [2, с. 165] та елективного курсу, метою якого є розширення 